\title{
Toxicity and Tissue Distribution of Aminophylline in Neonatal and Adult Mice and Rats
}

\author{
ALLEN L. NEESE AND LESTER F. SOYKA
}

Department of Pharmacology, College of Medicine, University of Vermont, Burlington, Vermont, USA

\section{Summary}

The $\mathbf{L D}_{50}$ of aminophylline in adult mice differed from young mice and rats of both ages, in which the values were remarkably similar (Table 1). With the exception of fat, which had lower concentrations in all groups, tissue concentrations after a $4 \mathbf{~ m g}$ / $\mathrm{kg}$ rectal dose of aminophylline in the 10-day-old animals ranged from $10-20 \mu \mathrm{g} / \mathrm{g}$ as compared to $4-10 \mu \mathrm{g} / \mathrm{g}$ in the adults (Table 2). To evaluate preferential distribution, an analysis of tissue to blood concentration ratios was made. All ratios approximated 1.0 except fat which had a ratio of $0.1-0.6$. The neonates of each species had significantly higher tissue to blood ratios for brain, heart, small intestine, skeletal muscle, and fat $(P<0.05)$. Brain to plasma and brain to blood ratios were very similar ranging from 0.4-1.3 in adults versus 0.8-1.7 in neonates. Considera- tion of the time course indicated a trend toward unit, with the overall ratio in both groups being 1.15 at $2 \mathrm{hr}$. However, at all earlier time periods the ratios were clearly higher in neonates. Administration of aminophylline intraperitoneally to produce serum concentrations of theophylline far in excess of the 10-20 $\mu \mathrm{g} / \mathrm{ml}$ considered to be safe and effective in clinical use did not decrease bilirubin levels in young or old Gunn rats (Fig. 1).

\section{Speculation}

The similarities of $\mathrm{LD}_{50}$ and tissue distribution between neonatal and adult rodents suggests that studies of metabolism may prove to be most important in explaining differences in serum elimination times noted in prematures treated with aminophylline. 


\section{INTRODUCTION}

The treatment of apnea of prematurity with aminophylline $(2,14,27,32)$ introduces questions regarding the pharmacology of the drug in imature patients. Previous measurements of elimination (serum half-1ives for the beta-phase) have established differences among individuals and between age groups. While mean half-lives for adults and children average 4.5 hours (22) average ca. 24 hours $(1,7,23)$.

Alterations in distribution secondary to immaturity may also contribute to age-related differences in toxicity. Such a change may be extremely important for a drug such as theophylline, which is known to exhibit significant central nervous system (CNS) toxicity in clinical use. For example. irritability and seizures have been reported in children and adults associated with high doses and elevated serum levels $(25,29,35)$.

Despite widespread use of aminophylline for over forty years (19), developmental studies in animals are lacking. Acute toxicity has been
determined in mice and rabbits $(8,13,20,31)$, tissue distribution studied determined in mice and rabbits $(8,13,20,31)$, tissue distribution studied in rabbits (26) and blood-CSF ratios
studies involved imnature animals.

The purpose of this investigation was to study the acute toxicity and tissue distribution of aminophylline, emphasizing the blood:brain ratio in young and older rodents. Since the rectal route of administration has been employed clinically $(2,14)$, it was included in the acute toxicity experiments and used for all groups in the distribution experiments. For adequate retention of the rectal solution, the young animals had to be at least ten days old. Mice and rats were used since brain myelination is delayed in these animals and resembles the preterm human $(10,33)$. As hyperbili rubinemia is common in premature infants, an in vivo assessment of the ability of theophylline to displace bilirubin from serum binding sites was studied in young and old jaundiced Gunn rats (9).

\section{MATERIALS}

Aminophylline Injection, U.S.P, $(25 \mathrm{mg} / \mathrm{ml})$ was a gift from Abbott Laboratories, North Chicago, I11. 3 H-theophylline (18.4 Ci/mnole) was purchased from Amersham/Searle Corp. Arlington Heights, I11. Soluene-350 PPO (2,5-diphenyloxazole), Dimethyl POPOP (1,4-bis-2-(4-methyl-5-phenyloxa-
zoly1)-benzene), bis MSB (p-bis-(0-methylstyry1)-benzene), and Triton X-100 zoly1)-benzene), bis MSB (p-bis-(0-methylstyry1)-benzene), and Triton X-100
were purchased from Packard Instrument Co., Downer's Grove, I11. Toluene, were purchased from Packard Instrument Co.; Downer's Grove, I1l. Toluene,
isopropyl alcohol, and hydrogen peroxide (308) were reagent grade and were purchased from Fisher Scientific. The Gunn rats were from the colony mainpurchased from Fisher Scientific. The Gunn rats were from the colony main Dawley rats were purchased from Canadian Breeders Labs., St. Constant, Quebec.

\section{METHODS}

Acute Toxicity. Groups of 6 - 40 ten-day-old, and adult mice $(30-40$ days old), and ten-day-old and adult rats $(250-350 \mathrm{~g})$, were given four to six graded doses of aminophyll ine ranging from 150 to $300 \mathrm{mg} / \mathrm{kg}$ i.p. (6-12 $u 1 / g)$. Six groups of ten-day-old mice were similarly dosed via tho rectal lethal doses precluded a similar study in adults. The number of dead animals was counted at two hours.

Tissue Distribution. Each of the four species-age groups was given $4 \mathrm{mg} / \mathrm{kg}$ per rectum aninophylline solution $(4 \mathrm{mg} / \mathrm{ml} \mathrm{with}$ 3 $\mathrm{H}$-theophylline $4 \mathrm{uCi} / \mathrm{ml}, \mathrm{l} \mathrm{ul} / \mathrm{g}$ ) via a Hamilton syringe, and decapitated at $15,30,60$, and 120 minutes. Tissues were dissected, a sample of blood, brain, lung, heart, liver, kidney, colon, small intestine, skeletal muscle, and subcutane
ous fat was weighed, placed in glass counting vial with $1 \mathrm{ml} / 100 \mathrm{mg}$ tissue ous fat was weighed, placed in glass count ing vial with $1 \mathrm{ml} / 100 \mathrm{mg}$ tissue
wt of Soluene-350/isopropanol $(1: 1)$ and solubilized at $40-50^{\circ} \mathrm{C}$ overnight. Bl eaching of colored samples, such as heart, liver and kidney, was accomplished by the addition of $0.2 \mathrm{ml}$ of $30 \%$ hydrogen peroxide/ml of Solueneplished by the addition of $0.2 \mathrm{ml}$ of $30 \mathrm{t}$ hydrogen peroxide/ml of Soluene-
isopropanol solution and incubation for $12-24$ hours at $40-50^{\circ} \mathrm{C}$. Ten ml of a "scintillation cocktail" (5 g PPO, $0.5 \mathrm{~g}$ bis-MSB/L of toluene) were of a "scintillation cocktail" (5 g PPO, $0.5 \mathrm{~g}$ bis-MSB/L of toluene) were
added and the samples stored in the dark at $25^{\circ} \mathrm{C}$ for more than 48 hours to minimize chemiluminescence. Radioactivity was determined in a Packard rri minimize chemiluminescence. Radioactivity was determined in a Packard Triaddition of an internal standard ( $3 \mathrm{H}$-theophylline). The efficiency of counting was used to calculate the activity of the sample in $\mathrm{dpm} / \mathrm{ml}$, and this was converted to ug theophylline/ mg tissue wet weight by determination of was converted to ug theophylline/ mg tissue wet weight by determination of
the specific activity of the solution administered. While this method did not differentiate theophylline from such possible metabolites as 1-methylnot differentiate theophylline from such possible metabolites as 1 -methyl-
xanthine and 3 -methylxanthine which would retain the $3 \mathrm{H}$ - in the $\mathrm{C}-8$ position, xanthine and 3-methylxanthine which would retain the $3 \mathrm{H}$ - in the $\mathrm{C}-8$ position,
Lohmann et al. (17) found no metabolism of theophylline in the brain, heart, Lohmann et al. (17) found no metabolism of theophylline in the brain, heart, lung, kidney, spleen, intestine, or adrenals of the rat. Moreover, the ana,
liver metabolites were the oxidized products, 1 -methyluric acid and $1,3-$ liver metabolites were the oxidized products, 1 -methyluric acid and 1,3-
dimethyluric acid, which would not be included in our determination of radioactivity. In addition, minor metabolites which would retain the radioradioactivity. In addition, minor metabolites which would retain the radioably in the short time of the experiment (two hours).

Blood-Brain Distribution. Ten-day-old and adult mice were given a sublethal dose of aminophylline $(50 \mathrm{mg} / \mathrm{kg})$ per rectum $(25 \mathrm{mg} / \mathrm{ml}$ with $3 \mathrm{H}$ theophylline $140 \mathrm{uCi} / \mathrm{ml}, 2 \mathrm{ul} / \mathrm{g})$, and groups of ten were decapitated at 15, 30,60 , and 120 minutes, the brains dissected, weighed, solubilized, and
radioactivity determined. Blood was collected in heparinized test tubes. Radioactivity in aliquots of plasma was determined in a "scintillation cocktail" (16.5 g PPO, 0.3 g Dimethy1 POPOP, $1 \mathrm{~L}$ Triton $\mathrm{X}-100$, and $2 \mathrm{~L}$ toluene). Efficiency of counting was determined by internal standardization and the concentration of theophylline was calculated as described above.

Bili rubin Displacement. Aminophylline was administered 1.p. to onemonth-old $(50 \mathrm{mg} / \mathrm{kg})$ and adult $(100 \mathrm{mg} / \mathrm{kg})$ homozygous Gunn rats. These animals suffer a genetically determined nonhemolytic unconjugated hyper$60,120,180$ minutes, and assayed for theophylline by radioimnunoassay (23) $60,120,180$ minutes, and assayed for theophylline by radioimnunoassay
and for bilirubin by the method of white, et al. (34). As a positive control sulfisoxazole ( $100 \mathrm{mg} / \mathrm{kg}$ i.p.), was administered to two adult Gunn rats.

Statistical procedures. The acute toxicity data were analyzed by the method of Miller and Tainter (21). The percentage of deaths was converted to probits and plotted versus the logarithm of the dose. The $L_{5}$ and its standard error were determined graphically. The slopes and intercepts for Cochran (28), except that differences were analyzed for all five lines instead of their two line model.
The tissue concentrations and tissue:blood ratios were analyzed by Analysis of Variance using a factorial design. For each tissue the contributions to the variance from species, age, and time difforences as well as the appropriate interactions were calculated.

\section{RESULTS}

Acute Toxicity. Deaths of the ten-day-old animals of both spectes age were able to withstand at least four hours separation from their mothers without apparent i11 effects. Deaths in the adult mice occurred within two hours of dosing, with no additional deaths occurring during a five day post-treatment observa$t$ ion period. In contrast, occasional additional deaths of adult rats occur
$12-24$ hours post-treatment. For this reason calculation of the $L D_{50}$ was based on deaths within the first two hours post-treatment.

Cause of death appeared to be central in origin, manifested by proseizures, opisthotonus, rigidity, and cessation of respiration. Late deaths of adult rats appeared to have another basis, since they were flaccid and had no evidenco of tonguebiting.

The LD 50 of aminophylline in adult mice differed from young mice and Analysis of the regression line (probits vs. log-dose) of adult mice rovealed that both its slope and intercept differed significantly $(P<.05)$ from those of the other four groups combined. Notably, the $L_{50}$ in ten-day old mice was
virtually the same when aminophylitine was given rectally as when given $1 . p$. (Table 1).

Tissue Distribution. Following administration of equivalent doses, based on body weight, concentr significantly greater in the 10-day-olds of both species than in the adults al groups, tissue concentrations after a $4 \mathrm{mg} / \mathrm{kg}$ rectal dose of aminophylline all groups, tissue concentrations after a $4 \mathrm{mg} / \mathrm{kg}$ rectal dose of aminophy
in the 10 -day-old animals ranged from 10 to $20 \mathrm{ug} / \mathrm{g}$ as compared to four in the 10-day-old animals ranged from 10 to $20 \mathrm{ug} / \mathrm{g}$ as compared to four
to $10 \mathrm{ug} / \mathrm{g}$ in the adults (Table $1 \mathrm{I}$ ). While no statistically significant to $10 \mathrm{ug} / \mathrm{g}$ in the adults (Table II). While no statistically significant
differences were found between time periods in any of the tissues, levels in differences were found between time periods in any of the tissues, levels in
the colon tended to be higher at 15 and 30 minutes than they were at one and

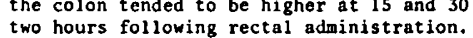

Species differences were found only in the heart and kidney. In both tissues, adult rats had significantly higher levels than did adult mice $(\mathrm{P}<0.05)$.

To evaluate preferential distribution, an analysis of tissue:blood fat which had a ratio of $0.1-0.6$. The neonates of each species had significantly higher tissue:blood ratios for brain, heart, small intestine, skeletal muscle, and fat $(p<0.05)$. The only tissue exhibiting a time dependency was fat

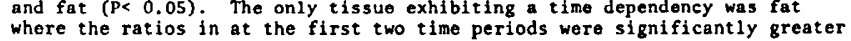
than in the last two in all groups except adult rats $(\mathrm{P}<0.01)$.

Species differences were found in three tissues. In adults brain:blood ratios were higher in mice, whereas the reverse was found for the kidney: blood were higher in mice $(p<0.05)$.

Blood-Brain Distribution. To further delineate the relative permeability of the blood-brain barrier of the neonate vs that of the adult, the dose administered per rectum was increased from 4 to $50 \mathrm{mg} / \mathrm{kg}$. This 12.5 -fold
increase in dose resulted in plasma concentrations that were, in adults, only increase in dose resulted in plasma concentrations that were, in adults, only
three- to four-fold greater than found in the previous experiment. In
neonates only a two-to three-fold increase was found one and two-hours postneonates only a two-to three-fold increase was found one and two-hours post eight-fold in adults, but only two-fold in neonates. Thus brain:plasma and brain:blood ratios were very similar ranging from $0.4-1.3$ in adults vs. $0.8-1.7$ in neonates. Consideration of the timo course indicated a trend toward unity, with the overall ratio in both groups being 1.15 at two hours. Howere, at all earlier time periods the ratios were clearly higher in neonates.

Displacement of Bilirubin. Administration of aminophylline i.p. to produce serum concentrations of theophylline far in excess of the $10-20 \mathrm{ug} / \mathrm{ml}$ considered to be safe and effective in clinical use did not decrease bilirubin levels in young or old Gunn rats (Figure 1). As expected, sulfisoxazole in equivalent dosage $(100 \mathrm{mg} / \mathrm{kg}$, 1 . p. $)$ produced decreases
serum bilirubin to $70 \%$ of control values at 30 and 60 minutes postadministration.

\section{DISCUSSION}

The acute toxicity of aminophylline, expressed as the $\mathrm{LD}_{50}$, from the present study in ten-day-old mice and in both ten-day-old and adult rats correlated well with those reported for adult rabbits (31), rats (4), and
cats (8). The data, viewed collectively, suggest an $L D_{50}$ of ca. $175 \mathrm{mg} / \mathrm{k}$ cats (8). The data, viewed collectively, suggest an $\mathrm{LD}_{50}$ of $\mathrm{ca} .175 \mathrm{mg} / \mathrm{kg}$
(i.p.). In contrast, a higher $L D_{50}$ (ca. $270 \mathrm{mg} / \mathrm{kg}$ ) was found in adult mice (i.p.). In contrast, a higher $\mathrm{LD}_{50}(\mathrm{ca} .270 \mathrm{mg} / \mathrm{kg})$ was found in adult mice
in our study and in previous reports $(6,12,13,19)$. Thus the data indicate that one must not as sume that an $L D_{50}$ will be lower for neonates than for that one must not assume that an $L_{50}$ will be lower for neonates than for adults, or merely make extrapolations from one species to another to estimate
relative doses, since inconsistencies can be found even between species as closely related as mice and rats.

Excessive stimulation of the CNS by aminophylline appeared to be the higher mamalian species such as cats and dogs (13). Likewise, excessive CNS stimulation, manifested by hyperirritability and seizures, has been reported in man following aminophylline overdosage $(29,35)$.

The clear differences in blood-brain distribution between ten-day-old and adult animals, while of interest, do not explain the age and species differences in $\mathrm{LD}_{50}$. The results do confirm that the so-called "blood-brain barrier" is less developed in innature mice and rats. Combining mean values at both doses and at all time periods yielded brain:blood ratios for neonatal
of 1.2 vs 0.7 for adult mice and values of 0.7 vs 0.35 for immaturo and adult rats. While this observation is compatible with and might be used to oxplain the age-related differences in $L D_{50}$ in mice, such reasoning cannot be applied
universally, because rats did not exhibit an age-related difference in LD

Tissue concentrations of theophylline were consistently and significantly higher in ten-day-old animals of both species, but tissue:blood ratios approximated unity. This observation is important, having been demonstrated for the use of serum and saliva theophylline concentrations for monitoring 
therapeutic and toxic effects. Calculated tissue compartment theophylline concentrations from a two-compartment pharmacokinetic model differ, and mus be interpreted cautiously. Paalzow (24) found the tissue compartment theophylline concentrations to be 2.3 times the central compartment concentrations in rats, whereas Levy and Koysooko (16) found the tissue compart ment values to be only about $20 \%$ of the central values in humans. However the central (plasma) theophylline concentrations correlate well with the pharmacologic effects $(16,24)$. The conclusions of Paalzow and of Levy and koysooko, as well as other studies in children $(15,18)$ and the data of the
present study all support the use of a one-compartment pharmacokinetic model

The known binding of theophylline by serum proteins generates concern over bilirubin displacement. Aranda et al. (1) have shown by an ultracentrifugation method that 358 (at a serum concentration of $17 \mathrm{ug} / \mathrm{ml}$ ) of theophyllin was protein bound in the cord plasma of neonates versus $56 \%$ in adult plasma. In their study, theophylline (15 ug/ml) did not reduce bilirubin binding as determined by the Sephadex -25 collon techlidue. Similarly Brodersen (3), using the peroxidase method, found theophylline to be a very weak bilirubin displacer, causing a $5 \%$ displacement at $10 \mathrm{ug} / \mathrm{ml}$. Our in vivo studies Gunn rats agree with these in vitro findings and support the view that neonatal apnea with theophylline.

\section{CONCLUSION}

Our results in animals support the general clinical experience regarding the safety of the use of aminophylline in neonates. Ten-dayold rodents were not more sensitive than adults to its lethal effects. Al though the $L D_{50}$ for newborn mice was less than that for adult mice, it was consistent with that found for adults of several other species, indicating that the adult mouse is unusually rosistant to this drug. The uniform distribution of theophyllino in body tissues supports the utility of serum theophylline lovels in monitoring therapeutic and toxic effects and the analysis of such data by a one-compartment pharmacokinetic model. The relatively greater permeability of the neonatal blood-brain barrier necessitates careful observation and avoidance of excessive serum levels to avoid CNS toxicity. Since the site of action may be
central respiratory chemoreceptors (5), relatively low serum concentrations may be sufficient for a therapeutic effect. Thus, while at present there are no data available as to optimum serum levels in prematures, such levels may prove to be different from the $10-20 \mathrm{ug} / \mathrm{ml}$ generaliy accepted as therapeutic and safe for treatment of bronchial asthma in children and adults.

We wish to thank Dr. Jerold F. Lucey and Mrs. Jean Hewitt for their assistance with the Gunn rat studies, Miss Ann Hughes for her technical assistance, and Mrs. Mary-Jane $J$. Dodds for her assistance in preparation of the manuscript.

\section{REFERENCES AND NOTES}

1. Aranda, J.V., Sitar, D.S., Parsons, W.D., Loughnan, P.M., and Neims, A.H.: Pharmacokinetic aspects of theophylline in premature newborns. N. Eng1. J. Med., 295: 413 (1976)

2. Bednarek, F. and Roloff, D.W.: Treatment of apnea of prematurity with aminophylline. Pediatrics, 58: 335 (1976).

3. Broderson, R. and Andersen, S.: Aminophylline, a weak bilirubin displacer. Pediatrics, 58: 463 (1976).

4 Chen, A.L.: Preliminary observations with theophylline mono-ethanolamine. J. Pharmacol. Exp. Ther., 45: 1 (1932).

5. Davi, M., Sankaran, K., Simons, K., Simons, E., Seshia, M.M., and Rigatto, H. Physiological changes induced by theophy11ine in the
treatment of apnea in preterm infants. Pediat. Res., 10: 422 (1976) Abstr. \#729.

6. Gardner, R.A., Hansen, A.E., Ewing, P.L., and Emerson, G.A.: Unexpected fatality in a child from accidental consumption of antibarbital. Texas State J. Med., 46: 516 (1950)

7. Giacoia, G., Jusko, W.J., Menka, J., Koup, J.R.: Theophylline pharmaco-

kinetics in premature infants with apnea. J. Pediatr. 89: 829 (1976) 1d, H., Travell, J., and Model1, W.: The effect of theophylline with ethylenediamine (aminophylline) on the course of cardiac infarction
following experimental coronary occlusion. Amer. Heart J., 14: 284 (1937).

9. Gunn, C.H.: Hereditary acholuric jaundice. J. Hered., 29: 137 (1938).

10. Jacobson, S.: Sequence of myelination in the brain of the albino rat. J. Comp. Neurol., 121: 5 (1963).

11. Jenne, J.W., Wyze, E., Rood, F.S., and MacDonald, F.M.: Pharmacokinetics of theophyiline. Application to adjustment of the clinical dose of aminophylline. Clin. Pharmacol. Ther., 13: 349 (1972).

12. Jensen, K.B.: Toxicity of dihydroxypropyl theophyliine and theophyllineethylene diamine. Arch. Pharm. Chem., 16:741 (1949).

13. Koch, R.: Zur Toxikologie verschiedener Theophyllinverbindungen und (1954)

14. Kuzenko, J.A., and Paala, J.: Apnoeic attacks in the newborn treated with aminophylline. Arch. Dis. Child., 48: 404 (1973).

15. Levy, G.: Pharmacokinetic control of theophylline therapy. In Levy, G., Clinical Pharmacokinetics - A symposium, Washington, D.C. (1974), American Pharmaceutical Association and the Academy of Pharmaceutical Scientists, pp 101-110.

16. Levy, G., Koysouko, R.: Pharmacokinetic analysis of the effect of 86: 789 (1975).

17. Lohmann, S.M., and Miech, R.P.: Theophylline metabolism by the rat liver microsomal system. J. Pharmacol. Exp. Ther., 196: 213 (1976).

18. Loughnan, P.M., Sitar, D.S., Ogilvie, R.I., Eisen, A., Fox, Z., and Neims, A.H.: Pharmacokinetic analysis of the disposition of intra-

19. May, C.D.: History of the introduction of theophylline into the treatment of asthma. Clin. Allerg., 4: 211 (1974).

20. McColl, J.D., Parker, J.M., and Ferguson, J.K.W.: A comparison of the relative toxic, emetic and convulsive actions of a series of methylated xanthine derivatives. J. Pharmacol. Exp. Ther., 116: 343 (1956)

21. Miller, L.C., and Tainter, M.L.: Estimation of the $\overline{E D}_{50}$ and its error by means of logarithmic-probit graph paper. Proc. Soc. Exp. Biol. Med.,

22. Mitenko, P.A., and Ogilvie, R.1.: Pharmacokinetics of intravenous theophylline. Clin. Pharmacol. Ther., 14: 509 (1973).

23. Neese, A. L. and Soyka, L.F. Devolopnent of a radioimunoassay for theophylline and its application to studies of premature infants. Clin. Pharmacol. Ther., in press.

24. Paalzow, L.K.: Pharmacokinetics of theophylline in relation to increased pain sensi
25. Rounds, V.J.: Aminophylline poisoning. Pediatrics, 14: 528 (1954).

26. Schack, J.A., and Waxler, S.H.: An ultraviolet spectrophotometric method for the determination of theophylline and theobrom

27. Shannon, D.C. Gotay, F, Stein, I.M., Rogers, M.C., Todres, I.D. Moylan, $\bar{M}$. B.: Prevention of apnea and bradycardia in low-birthweight Moylan, F.M.B.: Prevention of apnea
infants. Pediatrics, 55: 589 (1975).

28. Snedecor, G.W. and Cochran, W.G.: Statistical Methods (Iowa Stato University Press, Ames, Iowa, 1967).

29. Soifer, H.: Aminophylline toxicity, J. Pediatr., 50: 657 (1957).

30. Teschemacher, H.J., Herz, A., Hess, R., Novoczek, G.: Permeation of purine derivatives into the cerebrospinal fluid of dogs. Experientia, purine derivativ 54 (1968)

31. Thompson, C.R., and Warren, M.R.: Acute and chronic toxicity studies on theophylline aminoisobutanol and the
$J$. Lab. Clin. Med. $31: 1337(1946)$.

32. Uauy R. Shapiro, D.L. Smith, B., warshaw, J.B.: Treatment of severe apnea in prematures with orally administered theophylline. Pediatrics, apnea in premat 595 (1975).

33. Uzman, L.L., Rumley, M.K.: Changes in the composition of the developing mouse brain during early myelination. J. Neurochem, 3: 170 (1958)

34. White, D., Haidar, G. and Reinhold, J.G.: Spectrophotometric measurement of bilirubin concentrations in the serum of the newborn by the use of a microcapillary method. Clin. Chem., 4: 211 (1958).

35. Zwillich, C.W., Sut ton, F.. Neff, T.A., Cohn, W.M., Matthay, R.A., and Weinberger, M.M.: Theophylline-induced seizures in adults: 784 (1975)

36. This work was sunported in part by a Pharmaceutical Manufacturer's Association Foundation lledical Student Fellowship (ALN), the Ross Laboratories, and PHS Grant No. RO1-HD-08708 (LFS). Presented in part
at the Ross Conference on Apnea of Prematurity, November 20-21. 1975 at the Ross Conference on Apnea

37. Received for publication November $8,1976$.

38. Accepted for publication February 23, 1977

Table I. Acute toxicity of aminophylline

\begin{tabular}{lclcl}
\hline Spec1es & N & Age & Route & $L_{50}(\mathrm{mg} / \mathrm{kg}) \pm \mathrm{SE}$ \\
\hline Mice & $91^{\mathrm{a}}$ & 10 days & IP & $152 \pm 16$ \\
& 58 & 10 days & Rectal & $166 \pm 16$ \\
& 155 & Adult & IP & $273 \pm 5$ \\
Rats & 82 & 10 days & IP & $168 \pm 8$ \\
& 45 & Adult & IP & $188 \pm 10$
\end{tabular}

approximately equal numbers of males and females in each

group.

bolumes of injection $=1-2 \mathrm{ul} / \mathrm{g}$.

Table II. Concentrations of theophylline (ug/g) in various tissues at $15-120$ minutes administration of aminophylline
$(4 \mathrm{mg} / \mathrm{kg}$ per rectum, $1 \mathrm{ul} / \mathrm{g})$

\begin{tabular}{|c|c|c|c|c|c|c|c|c|}
\hline & & & & M I C & & & & \\
\hline & & ADUL & & & & 0 DAYS & & \\
\hline Time & 15 & 30 & 60 & 120 & 15 & 30 & 60 & 120 \\
\hline Blood ${ }^{a}$ & $\begin{array}{r}9.6 \\
2.0 \\
3\end{array}$ & $\begin{array}{r}11.0 \\
12.0 \\
5\end{array}$ & $\begin{array}{r}12.6 \\
5.0 \\
4\end{array}$ & $\begin{array}{r}4.2 \\
4.4 \\
4\end{array}$ & $\begin{array}{r}26.2 \\
1.8 \\
4\end{array}$ & $\begin{array}{r}21.0 \\
13.7 \\
6\end{array}$ & $\begin{array}{r}12.3 \\
7.6 \\
6\end{array}$ & $\begin{array}{r}11.3 \\
9.1 \\
5\end{array}$ \\
\hline Brain & $\begin{array}{r}5.8 \\
4.1 \\
4\end{array}$ & $\begin{array}{r}7.4 \\
6.0 \\
7\end{array}$ & $\begin{array}{r}4.1 \\
2.7 \\
6\end{array}$ & $\begin{array}{r}1.9 \\
1.5 \\
5\end{array}$ & $\begin{array}{r}19.8 \\
0.9 \\
4\end{array}$ & $\begin{array}{r}15.6 \\
11.8 \\
6\end{array}$ & $\begin{array}{r}15.8 \\
3.8 \\
6\end{array}$ & $\begin{array}{r}14.3 \\
6.5 \\
5\end{array}$ \\
\hline Lung & $\begin{array}{r}11.5 \\
7.2 \\
4\end{array}$ & $\begin{array}{r}9.3 \\
10.0 \\
7\end{array}$ & $\begin{array}{r}5.0 \\
3.8 \\
6\end{array}$ & $\begin{array}{r}1.9 \\
0.9 \\
4\end{array}$ & $\begin{array}{r}25.4 \\
1.8 \\
4\end{array}$ & $\begin{array}{r}20.8 \\
16.3 \\
6\end{array}$ & $\begin{array}{r}12.2 \\
8.3 \\
6\end{array}$ & $\begin{array}{r}12.8 \\
8.5 \\
5\end{array}$ \\
\hline Heart & $\begin{array}{r}8.0 \\
2.4 \\
3\end{array}$ & $\begin{array}{r}8.0 \\
6.8 \\
7\end{array}$ & $\begin{array}{r}4.9 \\
3.6 \\
6\end{array}$ & $\begin{array}{r}2.2 \\
1.1 \\
5\end{array}$ & $\begin{array}{r}27.3 \\
3.6 \\
4\end{array}$ & $\begin{array}{r}25.0 \\
16.5 \\
6\end{array}$ & $\begin{array}{r}19.3 \\
7.8 \\
6\end{array}$ & $\begin{array}{r}12.7 \\
7.1 \\
5\end{array}$ \\
\hline Liver & $\begin{array}{r}10.1 \\
6.6 \\
4\end{array}$ & $\begin{array}{r}3.8 \\
1.3 \\
6\end{array}$ & $\begin{array}{r}5.9 \\
4.2 \\
6\end{array}$ & $\begin{array}{r}4.0 \\
3.1 \\
5\end{array}$ & $\begin{array}{r}21.0 \\
1.9 \\
4\end{array}$ & $\begin{array}{r}20.4 \\
12.3 \\
6\end{array}$ & $\begin{array}{r}17.9 \\
4.9 \\
6\end{array}$ & $\begin{array}{r}11.4 \\
5.2 \\
5\end{array}$ \\
\hline Xidney & $\begin{array}{r}14.6 \\
6.8 \\
4\end{array}$ & $\begin{array}{r}5.2 \\
1.8 \\
6\end{array}$ & $\begin{array}{r}6.0 \\
5.9 \\
4\end{array}$ & $\begin{array}{r}3.0 \\
2.0 \\
5\end{array}$ & $\begin{array}{r}29.9 \\
2.2 \\
4\end{array}$ & $\begin{array}{r}26.6 \\
18.9 \\
6\end{array}$ & $\begin{array}{r}21.7 \\
7.3 \\
6\end{array}$ & $\begin{array}{r}15.1 \\
8.3 \\
5\end{array}$ \\
\hline Colon & $\begin{array}{r}15.4 \\
9.7 \\
4\end{array}$ & $\begin{array}{r}4.5 \\
1.5 \\
5\end{array}$ & $\begin{array}{r}7.3 \\
3.4 \\
6\end{array}$ & $\begin{array}{r}3.8 \\
2.5 \\
5\end{array}$ & $\begin{array}{r}24.1 \\
2.5 \\
2\end{array}$ & $\begin{array}{r}25.2 \\
19.1 \\
6\end{array}$ & $\begin{array}{r}21.3 \\
12.5 \\
6\end{array}$ & $\begin{array}{r}10.9 \\
7.5 \\
5\end{array}$ \\
\hline $\begin{array}{l}\text { Sna11 } \\
\text { Intest ine }\end{array}$ & $\begin{array}{r}10.7 \\
3.9 \\
4\end{array}$ & $\begin{array}{r}3.7 \\
1.3 \\
6\end{array}$ & $\begin{array}{r}5.2 \\
3.2 \\
6\end{array}$ & $\begin{array}{r}2.0 \\
0.9 \\
5\end{array}$ & $\begin{array}{r}27.3 \\
6.4 \\
4\end{array}$ & $\begin{array}{r}21.1 \\
16.7 \\
6\end{array}$ & $\begin{array}{r}19.3 \\
6.4 \\
6\end{array}$ & $\begin{array}{r}11.2 \\
6.4 \\
4\end{array}$ \\
\hline $\begin{array}{l}\text { Skeletal } \\
\text { Muscle }\end{array}$ & $\begin{array}{r}13.0 \\
7.5 \\
4\end{array}$ & $\begin{array}{r}3.8 \\
2.1 \\
6\end{array}$ & $\begin{array}{r}5.0 \\
3.0 \\
6\end{array}$ & $\begin{array}{r}2.1 \\
1.1 \\
5\end{array}$ & $\begin{array}{r}23.0 \\
2.2 \\
4\end{array}$ & $\begin{array}{r}19.0 \\
18.9 \\
6\end{array}$ & $\begin{array}{r}14.7 \\
9.9 \\
6\end{array}$ & $\begin{array}{r}13.0 \\
8.7 \\
4\end{array}$ \\
\hline Fat & $\begin{array}{r}7.9 \\
9.0 \\
4\end{array}$ & $\begin{array}{r}0.6 \\
0.4 \\
5\end{array}$ & $\begin{array}{r}0.7 \\
0.2 \\
6\end{array}$ & $\begin{array}{r}0.4 \\
0.4 \\
5\end{array}$ & $\begin{array}{r}12.0 \\
3.4 \\
4\end{array}$ & $\begin{array}{r}8.8 \\
9.5 \\
6\end{array}$ & $\begin{array}{r}6.8 \\
3.9 \\
5\end{array}$ & $\begin{array}{r}5.4 \\
3.0 \\
4\end{array}$ \\
\hline
\end{tabular}

${ }^{a}$ Values are mean, S.D., and $N$. 
Table II. Continued

\begin{tabular}{|c|c|c|c|c|c|c|c|c|}
\hline & & & & R A T & & & & \\
\hline & & ADUL & & & & 0 DAYS & & \\
\hline Time & 15 & 30 & 60 & 120 & 15 & 30 & 60 & 120 \\
\hline Blood $^{\mathrm{a}}$ & $\begin{array}{r}13.0 \\
9.4 \\
2\end{array}$ & $\begin{array}{r}11.7 \\
0.6 \\
2\end{array}$ & $\begin{array}{r}5.8 \\
2.7 \\
2\end{array}$ & $\begin{array}{r}8.9 \\
7.4 \\
2\end{array}$ & $\begin{array}{r}14.9 \\
9.4 \\
6\end{array}$ & $\begin{array}{r}20.0 \\
8.3 \\
6\end{array}$ & $\begin{array}{r}24.1 \\
1.4 \\
6\end{array}$ & $\begin{array}{r}22.0 \\
2.5 \\
5\end{array}$ \\
\hline Brain & $\begin{array}{r}5.2 \\
4.4 \\
2\end{array}$ & $\begin{array}{r}3.2 \\
0.9 \\
2\end{array}$ & $\begin{array}{r}3.3 \\
2.9 \\
2\end{array}$ & $\begin{array}{r}2.7 \\
1.9 \\
2\end{array}$ & $\begin{array}{r}9.8 \\
6.2 \\
5\end{array}$ & $\begin{array}{r}11.6 \\
6.4 \\
8\end{array}$ & $\begin{array}{r}16.5 \\
6.2 \\
6\end{array}$ & $\begin{array}{r}11.5 \\
5.3 \\
7\end{array}$ \\
\hline Lung & $\begin{array}{r}10.9 \\
6.6 \\
2\end{array}$ & $\begin{array}{r}9.7 \\
1.5 \\
2\end{array}$ & $\begin{array}{r}5.5 \\
2.2 \\
2\end{array}$ & $\begin{array}{r}9.4 \\
8.8 \\
2\end{array}$ & $\begin{array}{r}13.9 \\
8.4 \\
6\end{array}$ & $\begin{array}{r}15.4 \\
8.5 \\
8\end{array}$ & $\begin{array}{r}21.6 \\
6.9 \\
7\end{array}$ & $\begin{array}{r}15.3 \\
6.5 \\
7\end{array}$ \\
\hline Heart & $\begin{array}{r}14.6 \\
11.3 \\
2\end{array}$ & $\begin{array}{r}9.6 \\
1.9 \\
2\end{array}$ & $\begin{array}{r}5.0 \\
2.1 \\
2\end{array}$ & $\begin{array}{r}7.3 \\
5.8 \\
2\end{array}$ & $\begin{array}{r}15.4 \\
10.2 \\
6\end{array}$ & $\begin{array}{r}16.7 \\
10.3 \\
8\end{array}$ & $\begin{array}{r}23.4 \\
7.9 \\
7\end{array}$ & $\begin{array}{r}16.2 \\
7.1 \\
7\end{array}$ \\
\hline Liver & $\begin{array}{r}12.3 \\
8.1 \\
2\end{array}$ & $\begin{array}{r}10.2 \\
0.6 \\
2\end{array}$ & $\begin{array}{r}5.7 \\
2.7 \\
2\end{array}$ & $\begin{array}{r}7.9 \\
6.2 \\
2\end{array}$ & $\begin{array}{r}14.4 \\
8.6 \\
6\end{array}$ & $\begin{array}{r}16.2 \\
8.3 \\
8\end{array}$ & $\begin{array}{r}21.6 \\
7.5 \\
7\end{array}$ & $\begin{array}{r}14.6 \\
5.8 \\
7\end{array}$ \\
\hline Kidney & $\begin{array}{r}18.1 \\
10.3 \\
2\end{array}$ & $\begin{array}{r}15.5 \\
0.3 \\
2\end{array}$ & $\begin{array}{r}7.7 \\
2.4 \\
2\end{array}$ & $\begin{array}{r}19.1 \\
19.5 \\
2\end{array}$ & $\begin{array}{r}17.6 \\
10.4 \\
6\end{array}$ & $\begin{array}{r}19.8 \\
10.0 \\
8\end{array}$ & $\begin{array}{r}29.3 \\
9.7 \\
7\end{array}$ & $\begin{array}{r}20.2 \\
8.7 \\
7\end{array}$ \\
\hline Colon & $\begin{array}{r}20.4 \\
20.7 \\
2\end{array}$ & $\begin{array}{r}8.7 \\
0.6 \\
2\end{array}$ & $\begin{array}{r}4.7 \\
2.0 \\
2\end{array}$ & $\begin{array}{r}7.4 \\
5.9 \\
2\end{array}$ & $\begin{array}{r}13.5 \\
9.0 \\
6\end{array}$ & $\begin{array}{r}36.0 \\
17.3 \\
7\end{array}$ & $\begin{array}{r}23.7 \\
7.3 \\
7\end{array}$ & $\begin{array}{r}20.8 \\
9.2 \\
7\end{array}$ \\
\hline $\begin{array}{l}\text { Smal1 } \\
\text { Intestine }\end{array}$ & $\begin{array}{r}11.4 \\
7.7 \\
2\end{array}$ & $\begin{array}{r}10.4 \\
2.6 \\
2\end{array}$ & $\begin{array}{r}4.5 \\
1.5 \\
2\end{array}$ & $\begin{array}{r}9.3 \\
9.1 \\
2\end{array}$ & $\begin{array}{r}14.3 \\
9.9 \\
6\end{array}$ & $\begin{array}{r}17.6 \\
9.2 \\
8\end{array}$ & $\begin{array}{r}32.1 \\
16.2 \\
7\end{array}$ & $\begin{array}{r}17.7 \\
7.7 \\
7\end{array}$ \\
\hline $\begin{array}{l}\text { Skeletal } \\
\text { Muscle }\end{array}$ & $\begin{array}{r}10.2 \\
8.0 \\
2\end{array}$ & $\begin{array}{r}8.4 \\
1.3 \\
2\end{array}$ & $\begin{array}{r}4.4 \\
1.4 \\
2\end{array}$ & $\begin{array}{r}6.9 \\
4.6 \\
2\end{array}$ & $\begin{array}{r}13.6 \\
7.4 \\
6\end{array}$ & $\begin{array}{r}26.0 \\
11.0 \\
8\end{array}$ & $\begin{array}{r}22.3 \\
8.1 \\
7\end{array}$ & $\begin{array}{r}16.4 \\
7.4 \\
7\end{array}$ \\
\hline Fat & $\begin{array}{r}0.8 \\
0.4 \\
2\end{array}$ & $\begin{array}{r}1.0 \\
0.4 \\
2\end{array}$ & $\begin{array}{r}2.5 \\
2.4 \\
2\end{array}$ & $\begin{array}{r}1.1 \\
0.9 \\
2\end{array}$ & $\begin{array}{r}11.4 \\
10.4 \\
6\end{array}$ & $\begin{array}{r}8.2 \\
4.4 \\
7\end{array}$ & $\begin{array}{r}17.8 \\
4.3 \\
6\end{array}$ & $\begin{array}{r}6.3 \\
2.5 \\
7\end{array}$ \\
\hline
\end{tabular}

${ }^{a}$ Values are mean, S.D., and $\mathrm{N}$.

Table III. Comparison of blood-brain concentrationa of theophy111ne (ug/g) following adninietration of low $(4 \mathrm{mg} / \mathrm{kg})$ and $\mathrm{h}_{\mathrm{gh}}\left(90 \mathrm{mg} / \mathrm{kg}_{\mathrm{g}}\right)$ doses of aminophylline to neonatal and adult mice

\begin{tabular}{|c|c|c|c|c|c|c|c|c|}
\hline \multirow[b]{2}{*}{$\begin{array}{l}\text { Time } \\
\text { (min) }\end{array}$} & \multicolumn{4}{|c|}{ ADULT } & \multicolumn{4}{|c|}{$10 \mathrm{d.o.}$} \\
\hline & 15 & 30 & 60 & 120 & 15 & 30 & 60 & 120 \\
\hline \multicolumn{9}{|c|}{ Low dose $(N-3-6)$} \\
\hline Blood & $\begin{array}{l}9.6^{\mathrm{a}} \\
2.0\end{array}$ & $\begin{array}{l}11.0 \\
12.0\end{array}$ & $\begin{array}{r}12.6 \\
5.0\end{array}$ & $\begin{array}{l}4.2 \\
4.4\end{array}$ & $\begin{array}{l}26.2 \\
13.7\end{array}$ & $\begin{array}{l}21.0 \\
13.7\end{array}$ & $\begin{array}{r}12.3 \\
7.6\end{array}$ & $\begin{array}{r}11.3 \\
9.1\end{array}$ \\
\hline Brain & $\begin{array}{l}5.8 \\
4.1\end{array}$ & $\begin{array}{l}7.4 \\
6.0\end{array}$ & $\begin{array}{l}4.1 \\
2.7\end{array}$ & $\begin{array}{l}1.9 \\
1.5\end{array}$ & $\begin{array}{r}19.8 \\
0.9\end{array}$ & $\begin{array}{l}15.6 \\
11.9\end{array}$ & $\begin{array}{r}15.8 \\
3.8\end{array}$ & $\begin{array}{r}14.3 \\
6.5\end{array}$ \\
\hline$\frac{\text { Brain }}{\text { Blood }}$ & 0.5 & 0.8 & 0.4 & 1.0 & 0.8 & 0.8 & 1.6 & 1.3 \\
\hline
\end{tabular}

High dose $(\mathrm{N}=10)$

$\begin{array}{lrrrrrrrr}\text { Plasma } & 53.7 & 32.0 & 33.3 & 18.1 & 31.3 & 19.2 & 26.7 & 29.3 \\ & 44.4 & 21.9 & 25.2 & 14.5 & 12.0 & 6.8 & 7.7 & 11.9 \\ \text { Brain } & 19.6 & 13.3 & 18.3 & 17.5 & 27.8 & 29.5 & 30.3 & 27.0 \\ & 12.6 & 7.0 & 9.5 & 6.2 & 6.3 & 6.2 & 3.5 & 8.6 \\ \text { Braln } & 0.5 & 0.5 & 0.8 & 1.3 & 1.0 & 1.7 & 1.3 & 1.0 \\ \text { P1asma } & & & & & & & & \end{array}$

${ }^{a}$ Values are mean and S.D.

Conyright (c) 1977 International Pediatric Research Foundation, Inc.

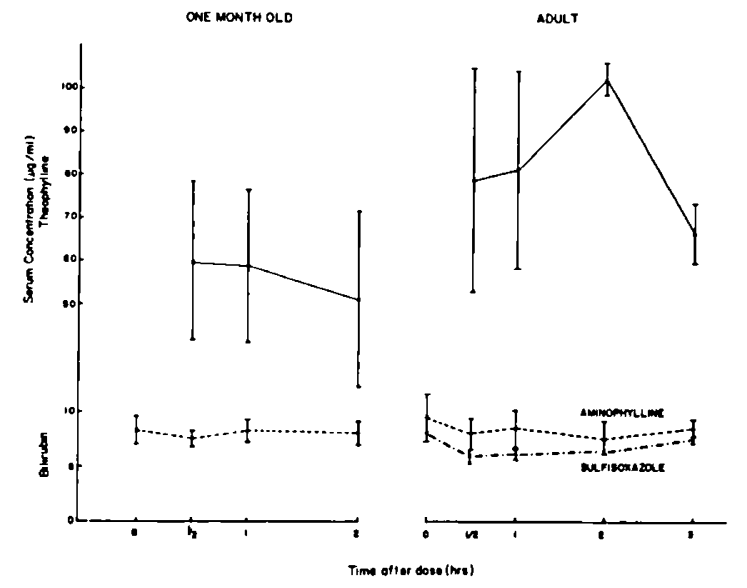

Fig. 1. Serum levels of theophylline and bilirubin (mean \pm S.D.) after IP injection of aminophylline to one-month old $(50 \mathrm{mg} / \mathrm{kg}, \mathrm{N}=8)$ and adult Gunn rats $(100 \mathrm{mg} / \mathrm{kg}$, given sulfisoxazole $(100 \mathrm{mg} / \mathrm{kg})$ has been included. 